\title{
Socioeconomic inequalities in cancer survival in Scotland $1986-2000$
}

\author{
LG Shack ${ }^{*, 1,2}$, B Rachet', DH Brewster ${ }^{3}$ and MP Coleman' \\ 'Non-Communicable Disease Epidemiology Unit, London School of Hygiene and Tropical Medicine, Keppel Street, London WCIE 7HT, UK; ${ }^{2}$ North West \\ Cancer Intelligence Service, 2nd Floor Muspratt Building, University of Liverpool, Liverpool L69 3GB, UK; ${ }^{3}$ Scottish Cancer Registry, NHS National Services \\ Scotland, Gyle Square, I South Gyle Crescent, Edinburgh EHI 2 9EB, UK
}

We analysed trends in 5-year survival of the 18 commonest cancers in Scotland diagnosed between 1986 and 2000 and followed up to 2004 in each of five deprivation groups based on patients postcode of residence at diagnosis. We estimated relative survival up to 5 years after diagnosis, adjusting for the different background mortality in each deprivation group by age, sex and calendar period. We estimated trends in overall survival and in the deprivation gap in survival up to 2004. Five-year survival improved for all malignancies except bladder cancer and was associated with a widening in the deprivation gap in survival. For 25 of 30 cancer-sex combinations examined, 5-year survival was lower among more deprived patients diagnosed during 1996-2000, and the deprivation gap in survival had widened since 1986-1990 for 15 of these 25 cancers, similar to the trends seen in England and Wales.

British Journal of Cancer (2007) 97, 999- 1004. doi:10.1038/sj.bjc.6603980 www.bjcancer.com

Published online 18 September 2007

(c) 2007 Cancer Research UK

Keywords: deprivation; socioeconomic inequalities; relative survival; Scotland

Cancer survival is known to vary by socioeconomic level in many parts of the world (Kogevinas and Porta, 1997; Woods et al, 2006). In England and Wales, such inequalities have been demonstrated for most adults diagnosed with cancer during 1971-1990 (Coleman et al, 1999). Survival improved for adults diagnosed with the 20 most common cancers in England and Wales during the period 1986-1999, but socioeconomic inequalities in survival widened (Coleman et al, 2004).

In Scotland, despite substantial recent improvements in survival (Scottish Cancer Intelligence Unit, 2004), cancer mortality has historically been higher, and survival lower, than in England and Wales (Coleman et al, 2003; Quinn et al, 2005). To the extent that the link between survival and socioeconomic status is causal, the lower survival in Scotland may be partly attributable to a lower average socioeconomic level (Griffiths and Fitzpatrick, 2001). Socioeconomic inequalities in cancer survival in Scotland have been examined, but to our knowledge, trends in these inequalities have not been evaluated. We investigated socioeconomic differences in cancer survival among patients diagnosed in Scotland during 1986-2000, and trends in these inequalities over time.

\section{MATERIALS AND METHODS}

We examined the data for 357658 adults (aged 15-99 years) diagnosed with a first, invasive, primary, malignant neoplasm

\footnotetext{
*Correspondence: LG Shack, North West Cancer Intelligence Service, 2nd Floor Muspratt Building, University of Liverpool, Liverpool L693GB, UK; E-mail: lorraine.shack@mccr.nhs.uk

Received 27 April 2007; revised 8 August 2007; accepted 15 August 2007; published online 18 September 2007
}

(excluding nonmelanoma skin cancer, ICD-10 C00-C97 excluding C44) in Scotland between 1 January 1986 and 31 December 2000 (the most recent year of complete data available at the time) and registered at the Scottish Cancer Registry. Incident cases were linked to death details provided by the General Register Office for Scotland. Data were extracted for analysis on 13 April 2005. The vital status was considered to be known for all patients up to 31 December 2004. Patients identified from a death certificate only were excluded (3.4\% of all registrations). About $8.5 \%$ of records (31 982) with a second or later tumours were excluded.

Patients were matched to socioeconomic categories based on their postcode of residence at diagnosis, using the 1991 censusderived Carstairs Deprivation Index Score (Carstairs, 1995) for those diagnosed during 1986-1995 and the Scottish Indices of Multiple Deprivation (IMD) 2004 score for those diagnosed during 1996-2000 (General Register Office for Scotland, 2006). Socioeconomic category was based on the geographic level of postcode sector $(n=4660)$ for Carstairs and data zone $(n=770)$ for IMD. The combined IMD score was used to assign deprivation, rather than only the income domain score, because this was consistent with the Carstairs deprivation group and is the system used by the Scottish Cancer Registry (Measuring Deprivation Subgroup, 2004). The five deprivation categories were derived from quintiles of the national distribution of area deprivation scores in Scotland.

Methods for analysis have previously been published (Coleman et al, 2004). Briefly, relative survival at 5 years after diagnosis was estimated for patients diagnosed with cancer and resident in Scotland. Relative survival is the ratio of observed survival of cancer patients and the survival that would have been expected if the patients had had the same age-, deprivation- and sex-specific mortality in each period as the general population (Berkson and Gage, 1950). Period life tables by single year of age (up to 99 years), 
sex and deprivation category were derived from the numbers of deaths for 1990-1992 and 2000-2002 (General Register Office for Scotland, 2006). Corresponding population denominators were drawn from the 1991 and 2001 census populations from the General Register Office for Scotland (2006).

Relative survival was estimated for each of the 20 most common cancers by deprivation category and sex for each of three periods of diagnosis; 1986-1990, 1991-1995 and 1996-2000. The 19901992 life tables were used to estimate background mortality for patients dying in 1986-1995 and the 2000-2002 life tables for those dying in 1996-2004.

We used the maximum likelihood approach for individual records (Estève et al, 1990) to estimate relative survival using an algorithm developed for similar analyses (Coleman et al, 2004) in STATA software (Statacorp, 2004). Survival probabilities were estimated monthly for the first 6 months, then quarterly up to 1 year, then every 6 months from 1 year to 5 years. Survival for cancer of the larynx was estimated using monthly intervals up to 6 months, then 6 monthly up to 3 years and yearly up to 5 years. The cohort approach was used for patients diagnosed during 1986-1990 and 1991-1995, while 5-year survival was based on the complete approach for those diagnosed in 1996-2000.

Variance-weighted linear regression (Grizzle et al, 1969) was used to estimate temporal change in survival and the survival gradient across deprivation categories. For each time period, the 'deprivation gap' in survival was estimated as the absolute fitted difference between 5-year survival in the most deprived and the most affluent categories, estimated from the regression model (Coleman et al, 2004; Figure 1). The deprivation gap is described as negative if survival is lower in the most deprived than the most affluent group. Temporal change in the deprivation gap was estimated by inclusion in the model of an interaction term between period of diagnosis and deprivation group.

Survival could not be reliably estimated within deprivation groups for cancers of the pancreas, testis or larynx (women), due to small numbers of cases and/or deaths in some intervals after diagnosis. Survival is high for testicular cancer, and for laryngeal cancer in women, and very few deaths occurred 3-5 years after diagnosis. Most pancreatic cancer patients died within a year of diagnosis.

\section{RESULTS}

Five-year relative survival improved for most malignancies during the period 1986-2000 (Table 1). It increased rapidly, at $7-8 \%$ every 5 years, for cancers of the breast (women) and rectum (both sexes), and for all leukaemias combined (both sexes).

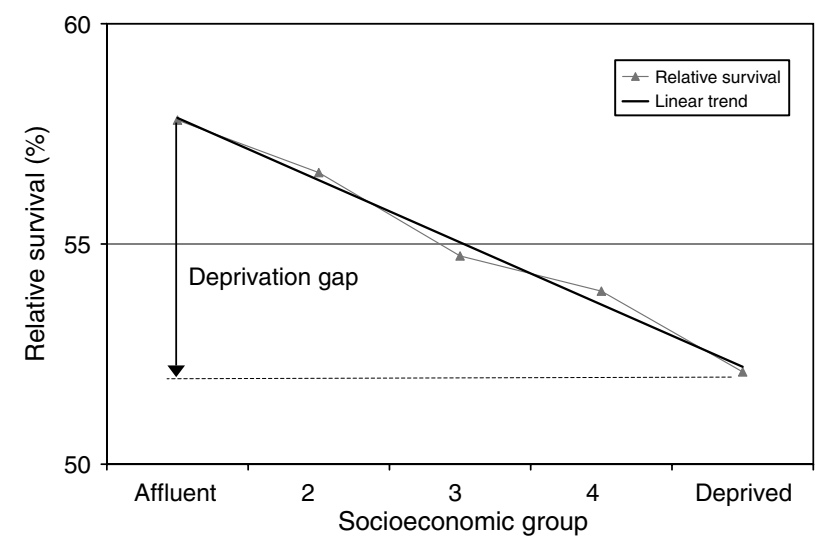

Figure I Fitted deprivation gap in 5-year relative survival (\%): colon cancer, Scotland, men diagnosed during 1996-2000.
Five-year survival from prostate cancer rose by an average of $11 \%$ every 5 years.

For patients diagnosed during 1996-2000, the deprivation gap in survival was negative (survival lower among the deprived than the affluent) for 25 of the 30 cancer-sex combinations, and statistically significant for 9 of these: colon (both sexes), rectum (women), larynx (men), lung (men), melanoma (women), breast (women), prostate and bladder (men; Table 1).

The deprivation gap in survival was negative for 15 of the 25 cancers diagnosed among patients during 1996-2000, the deprivation gap had widened significantly since 1986 . By contrast, the deprivation gap in survival became significantly smaller over the same period for oesophagus (men), stomach (men), brain (men), non-Hodgkin's lymphoma (men), myeloma (women) and leukaemia (men).

Differences in 5-year survival patterns between men and women were observed for all 12 cancers included in the analysis that arise in both sexes. The deprivation gap widened for all these cancers among women, but it was almost stable among men. So, whereas women diagnosed during 1986-1990 experienced a clear survival advantage over men (data not shown), this advantage having disappeared for those diagnosed during 1996-2000.

The deprivation gap widened for uterine cancer, but not for cancers of the breast (women), ovary or cervix. By contrast, the deprivation gap widened by about $3 \%$ every 5 years for cancers of the larynx (men) and prostate, leading to large socioeconomic differences in survival by $1996-2000$.

Bladder cancer survival decreased over time in both sexes, but women had significantly lower survival than men. The deprivation gap in survival widened by about $-4 \%$ every 5 years, reaching $-7 \%$ for patients diagnosed during 1996-2000.

Five-year survival from brain tumours in women was $16 \%$ during 1986-1990, but fell from $20 \%$ for $1991-1995$ to $17 \%$ for women diagnosed during 1996-2000. Survival from brain tumours in men improved more in the poor than the rich, so that the deprivation gap had actually reversed $(+4 \%$ in $1996-2000)$ with higher survival in the most deprived group.

Survival for non-Hodgkin's lymphoma and myeloma improved by about $5 \%$ every 5 years, and leukaemia survival improved even more rapidly, by about $8 \%$ every 5 years. No significant socioeconomic difference in survival was seen for any of the haematological malignancies.

\section{DISCUSSION}

For cancer patients diagnosed in Scotland during 1996-2000, 5 -year survival was lower among those who lived in more deprived areas. The socioeconomic inequality in survival worsened over the 15-year period 1986-2000, particularly among women.

Socioeconomic differences in cancer survival have been observed in many countries (Kogevinas and Porta, 1997; Ward et al, 2004), including the Netherlands (Schrijvers et al, 1995a), Canada (Mackillop et al, 1997), England and Wales (Coleman et al, 1999), Scotland (Scottish Cancer Intelligence Unit, 2000) and the United States (Singh et al, 2003). In England and Wales, recent improvements in survival have been more marked in affluent groups, actually widening the socioeconomic inequality in survival (Coleman et al, 2004). Our findings are broadly consistent with these studies, both on socioeconomic inequalities in survival and worsening of those inequalities over time. It remains to be determined whether the deprivation gap in survival is widening in other countries.

Further investigation is required, not only to identify the causes of socioeconomic inequality in survival, but also to find out why the inequality is becoming worse, not better.

We assumed linearity when modelling the association between survival and deprivation (five categories), and secular trend in the 


\begin{tabular}{|c|c|c|c|c|c|c|c|c|c|c|}
\hline \multirow[b]{3}{*}{ Malignancy } & \multicolumn{6}{|c|}{ Five-year relative survival (\%) } & \multicolumn{4}{|c|}{ Deprivation gap in 5-year survival (\%) ${ }^{a}$} \\
\hline & \multicolumn{3}{|c|}{$\begin{array}{l}\text { Patients diagnosed during } 1996- \\
2000\end{array}$} & \multicolumn{3}{|c|}{$\begin{array}{l}\text { Average change }(\%) \text { every } 5 \text { years over the period } \\
\qquad 1986-2000^{\mathrm{b}}\end{array}$} & \multicolumn{2}{|c|}{$\begin{array}{l}\text { Patients diagnosed during } \\
\text { 1996-2000 }\end{array}$} & \multicolumn{2}{|c|}{$\begin{array}{l}\text { Average change (\%) every } 5 \text { years } \\
\text { over the period } 1986-2000\end{array}$} \\
\hline & $\begin{array}{c}\text { No. of } \\
\text { patients }\end{array}$ & $\begin{array}{l}\text { Five-year } \\
\text { survival (\%) }\end{array}$ & $95 \% \mathrm{Cl}$ & No. of patients & Change (\%) & $95 \% \mathrm{Cl}$ & $\begin{array}{l}\text { Deprivation } \\
\text { gap (\%) }\end{array}$ & $95 \% \mathrm{Cl}$ & Change (\%) & $95 \% \mathrm{Cl}$ \\
\hline $\begin{array}{l}\text { Oesophagus } \\
\text { Men } \\
\text { Women }\end{array}$ & $\begin{array}{l}2109 \\
1424\end{array}$ & $\begin{array}{r}10.1 \\
9.8\end{array}$ & $\begin{array}{l}8.7-11.6 \\
8.2-11.6\end{array}$ & $\begin{array}{l}6302 \\
4666\end{array}$ & $\begin{array}{l}2.3^{c} \\
0.7\end{array}$ & $\begin{array}{l}1.5-3.2 \\
-0.5 \text { to } 1.8\end{array}$ & $\begin{array}{l}-0.4 \\
-4.6\end{array}$ & $\begin{array}{l}-4.6 \text { to } 3.9 \\
-9.3 \text { to } 0.2\end{array}$ & $\begin{array}{r}1.1^{c} \\
-2.4^{c}\end{array}$ & $\begin{array}{c}0.5-1.8 \\
-3.2 \text { to }-1.5\end{array}$ \\
\hline $\begin{array}{l}\text { Stomach } \\
\text { Men } \\
\text { Women }\end{array}$ & $\begin{array}{l}2583 \\
1768\end{array}$ & $\begin{array}{l}15.5 \\
16.1\end{array}$ & $\begin{array}{l}\mid 3.9-17.1 \\
|4.2-| 8.1\end{array}$ & $\begin{array}{l}9586 \\
6479\end{array}$ & $\begin{array}{l}2.7^{c} \\
2.4^{c}\end{array}$ & $\begin{array}{l}1.4-3.9 \\
1.4-3.5\end{array}$ & $\begin{array}{r}1.5 \\
-2.7\end{array}$ & $\begin{array}{l}-2.8 \text { to } 5.8 \\
-7.8 \text { to } 2.5\end{array}$ & $\begin{array}{r}0.8^{c} \\
-2.6^{c}\end{array}$ & $\begin{array}{c}0.1 \text { to } 1.4 \\
-3.5 \text { to }-1.8\end{array}$ \\
\hline $\begin{array}{l}\text { Colon } \\
\text { Men } \\
\text { Women }\end{array}$ & $\begin{array}{l}4969 \\
5061\end{array}$ & $\begin{array}{l}50.8 \\
51.0\end{array}$ & $\begin{array}{l}49.0-52.4 \\
49.4-52.6\end{array}$ & $\begin{array}{l}15409 \\
17216\end{array}$ & $\begin{array}{l}4.6^{c} \\
4.9^{c}\end{array}$ & $\begin{array}{l}3.2-6.0 \\
3.7-6.1\end{array}$ & $\begin{array}{l}-5.7^{c} \\
-6.1^{c}\end{array}$ & $\begin{array}{l}-10.1 \text { to }-1.2 \\
-10.2 \text { to }-1.9\end{array}$ & $\begin{array}{l}-4.4^{c} \\
-2.4^{c}\end{array}$ & $\begin{array}{l}-5.2 \text { to }-3.5 \\
-3.2 \text { to }-1.6\end{array}$ \\
\hline $\begin{array}{l}\text { Rectum } \\
\text { Men } \\
\text { Women }\end{array}$ & $\begin{array}{l}3190 \\
2227\end{array}$ & $\begin{array}{l}53.0 \\
56.0\end{array}$ & $\begin{array}{l}50.9-55.1 \\
53.4-58.5\end{array}$ & $\begin{array}{l}9506 \\
7291\end{array}$ & $\begin{array}{l}7.8^{c} \\
8.1^{c}\end{array}$ & $\begin{array}{l}6.1-9.5 \\
5.6-10.6\end{array}$ & $\begin{array}{l}-5.3 \\
-8.0^{c}\end{array}$ & $\begin{array}{c}-10.7 \text { to } 0.2 \\
-14.5 \text { to }-1.5\end{array}$ & $\begin{array}{l}-0.7 \\
-2.9^{c}\end{array}$ & $\begin{array}{c}-1.8 \text { to } 0.4 \\
-4.1 \text { to }-1.7\end{array}$ \\
\hline $\begin{array}{l}\text { Lanynx } \\
\text { Men }\end{array}$ & 1128 & 67.3 & $63.7-70.6$ & 3571 & 2.9 & -0.9 to 6.7 & $-10.8^{c}$ & -19.9 to -1.8 & $-3.2^{c}$ & -5.0 to -1.4 \\
\hline $\begin{array}{l}\text { Lung } \\
\text { Men } \\
\text { Women }\end{array}$ & $\begin{array}{r}12055 \\
8796\end{array}$ & $\begin{array}{l}7.1 \\
8.1\end{array}$ & $\begin{array}{l}6.6-7.6 \\
7.5-8.7\end{array}$ & $\begin{array}{l}43414 \\
26707\end{array}$ & $\begin{array}{l}0.3^{c} \\
0.8^{c}\end{array}$ & $\begin{array}{l}0.1-0.6 \\
0.0-1.7\end{array}$ & $\begin{array}{l}-1.6^{c} \\
-1.5\end{array}$ & $\begin{array}{c}-3.1 \text { to }-0.1 \\
-3.3 \text { to } 0.4\end{array}$ & $\begin{array}{l}-0.6^{c} \\
-1.2^{c}\end{array}$ & $\begin{array}{l}-0.9 \text { to }-0.3 \\
-1.5 \text { to }-0.9\end{array}$ \\
\hline $\begin{array}{l}\text { Melanoma } \\
\text { Men } \\
\text { Women }\end{array}$ & $\begin{array}{l}1266 \\
1766\end{array}$ & $\begin{array}{l}85.2 \\
94.6\end{array}$ & $\begin{array}{l}82.5-87.6 \\
92.8-95.9\end{array}$ & $\begin{array}{l}3671 \\
5511\end{array}$ & $\begin{array}{l}4.0^{c} \\
1.4^{c}\end{array}$ & $\begin{array}{l}1.3-6.7 \\
0.2-2.6\end{array}$ & $\begin{array}{l}-5.9 \\
-4.0^{c}\end{array}$ & $\begin{array}{l}-12.3 \text { to } 0.5 \\
-7.6 \text { to }-0.5\end{array}$ & $\begin{array}{r}1.3 \\
-1.9^{c}\end{array}$ & $\begin{array}{c}-0.1 \text { to } 2.8 \\
-2.8 \text { to }-1.1\end{array}$ \\
\hline $\begin{array}{l}\text { Breast } \\
\quad \text { Women }\end{array}$ & 16092 & 81.6 & $80.8-82.3$ & 49910 & $6.8^{c}$ & $5.9-7.7$ & $-4.1^{c}$ & -6.0 to -2.2 & -0.2 & -0.6 to 0.2 \\
\hline $\begin{array}{l}\text { Cervix } \\
\text { Women }\end{array}$ & 1654 & 70.9 & $68.3-73.2$ & 6265 & $3.7^{c}$ & ।.8-5.5 & -4.6 & -10.8 to 1.6 & 0.2 & -1.0 to 1.3 \\
\hline $\begin{array}{l}\text { Uterus } \\
\text { Women }\end{array}$ & 1930 & 81.2 & $78.8-83.3$ & 5821 & $2.9^{c}$ & $0.5-5.3$ & -5.2 & -10.7 to 0.3 & $-4.7^{c}$ & -5.8 to -3.5 \\
\hline $\begin{array}{l}\text { Ovary } \\
\text { Women }\end{array}$ & 2869 & 41.1 & $39.1-43.1$ & 9162 & $5.3^{c}$ & $3.4-7.3$ & -0.4 & -5.6 to 4.8 & 0.8 & -0.2 to 1.7 \\
\hline $\begin{array}{l}\text { Prostate } \\
\text { Men }\end{array}$ & 9370 & 72.0 & $70.7-73.4$ & 26673 & $10.8^{c}$ & $8.4-12.7$ & $-6.9^{c}$ & -10.3 to -3.4 & $-2.9^{c}$ & -3.7 to -2.2 \\
\hline $\begin{array}{l}\text { Bladder } \\
\text { Men } \\
\text { Women }\end{array}$ & $\begin{array}{l}308 \mid \\
|45|\end{array}$ & $\begin{array}{l}62.6 \\
51.8\end{array}$ & $\begin{array}{l}60.2-64.8 \\
48.6-54.9\end{array}$ & $\begin{array}{r}12139 \\
5521\end{array}$ & $\begin{array}{l}-1.5 \\
-2.5\end{array}$ & $\begin{array}{l}-5.1 \text { to } 2.2 \\
-6.0 \text { to } 1.0\end{array}$ & $\begin{array}{l}-6.7^{c} \\
-7.3\end{array}$ & $\begin{array}{l}-12.6 \text { to }-0.8 \\
-15.4 \text { to } 0.7\end{array}$ & $\begin{array}{l}-4.0^{c} \\
-3.9^{c}\end{array}$ & $\begin{array}{l}-5.1 \text { to }-3.0 \\
-5.3 \text { to }-2.4\end{array}$ \\
\hline $\begin{array}{l}\text { Kidney } \\
\text { Men } \\
\text { Women }\end{array}$ & $\begin{array}{l}1532 \\
1066\end{array}$ & $\begin{array}{l}44.1 \\
45.9\end{array}$ & $\begin{array}{l}41.2-47.0 \\
42.4-49.3\end{array}$ & $\begin{array}{l}4612 \\
3240\end{array}$ & $\begin{array}{l}2.2 \\
5.4^{c}\end{array}$ & $\begin{array}{l}-0.3 \text { to } 4.6 \\
3.2-7.6\end{array}$ & $\begin{array}{l}-5.2 \\
-4.8\end{array}$ & $\begin{array}{l}-12.8 \text { to } 2.4 \\
-13.8 \text { to } 4.2\end{array}$ & $\begin{array}{c}-3.1^{c} \\
0.3\end{array}$ & $\begin{array}{l}-4.6 \text { to }-1.5 \\
-1.4 \text { to } 2.1\end{array}$ \\
\hline
\end{tabular}


deprivation gap in survival (three time periods). Flexible functions which allow nonlinear relationships were used to test this assumption (Royston and Ambler, 1998), but no significant departure from linearity was detected.

In a study of breast cancer survival using ecological deprivation indices in England and Wales, the size of geographic unit was found to be more important than the choice of deprivation index (Woods et al, 2005). The socioeconomic status assigned to a given postcode sector may also change over time, but a Scottish study found that $80 \%$ of postcode sectors in Scotland remained in the same category or only shifted by one socioeconomic group between censuses (Measuring Deprivation Subgroup, 2004).

A similar study carried out in England and Wales was based only on the income domain of the IMD, because health-related factors are a component part (if small) of the overall index (Coleman et al, 2004). The complete IMD was recommended for the analysis of Scottish Cancer Registry data, however, because the differential impact was small (Measuring Deprivation Subgroup, 2004).

Possible explanations for socioeconomic variations in survival include variations in comorbidity (Schrijvers et al, 1997), stage at diagnosis (Schrijvers et al, 1995b; Ionescu et al, 1998; Brewster et al, 2001) and treatment (Campbell et al, 2002; Hole and McArdle, 2002; Jack et al, 2006). Only a few studies have adjusted for these factors, or examined their interaction with deprivation. The inequalities in survival have frequently been attributed to more deprived patients presenting at a later clinical stage, but even after adjustment for clinical stage at diagnosis, deprivation differences in survival persist (Schrijvers et al, 1995a, b; Campbell et al, 2002). Treatment access has also been seen to vary by socioeconomic factors (Madison et al, 2004). However, to our knowledge, only one study has evaluated changes over time in deprivation-specific survival and in the deprivation gap (Coleman et al, 2004). Temporal changes in prognostic factors that might explain the widening deprivation gap in survival should be investigated, for example, trends in socioeconomic differences in comorbidity, or in access to health care.

Deprivation-specific survival cannot be directly compared between England and Wales and Scotland because the deprivation measures are not defined identically in each country, but comparison of relative changes can be evaluated. Overall, Scotland has higher levels of deprivation than England and Wales (Griffiths and Fitzpatrick, 2001). On average, the deprivation gap in survival for most cancers was larger in Scotland than in England and Wales over the 15-year period 1986-2000 (data not shown). However, the overall picture was very similar, namely a clear deprivation gap in survival which has widened since the late 1980s.

Socioeconomic gradients in colorectal cancer survival may be explained by differences in treatment (Faivre-Finn et al, 2002; Guyot et al, 2005; Yu et al, 2005), stage at diagnosis (Singh et al, 2003) or comorbidity (Schrijvers et al, 1995a; Wrigley et al, 2005), although such differences are not consistent (Ionescu et al, 1998; Brewster et al, 2001; Wrigley et al, 2005). In Scotland, deprived and affluent patients diagnosed during 1991-1994 had similar curative resection rates, but survival was lower among deprived patients, even after adjusting for stage at diagnosis and type of operation (Hole and McArdle, 2002). Stage at diagnosis and treatment are the most important influences on colorectal cancer survival, but their interaction with deprivation remains unclear.

Melanoma of the skin has become increasingly common in the more affluent, particularly women, probably due to an increased ultra-violet exposure. Survival is high in the Nordic countries, but also, uncharacteristically, in Scotland (Coleman et al, 2003), probably due to a successful education campaign (MacKie et al, 2002) and the increasing proportion of thin tumours (MacKie et al, 1997). Despite the high 5-year survival, the deprivation gap in relative survival remains substantial $(-6 \%$ in $\mathrm{men},-4 \%$ in women). 
The deprivation gap in survival for breast and cervical cancer was $4-5 \%$, but it remained stable throughout the period 19862000, as in England and Wales (Coleman et al, 2004). Population screening programmes were introduced in Scotland for cervical cancer in 1988 and breast cancer during the 1990s: uptake was higher in more affluent groups, as has been observed in England (Banks et al, 2002; Maheswaran et al, 2006), the United States (Kothari and Birch, 2004), Canada (Katz and Hofer, 1994) and the Netherlands (Louwman et al, 2007). Thus, $81 \%$ of affluent women attended the breast-screening programme during 1999-2002, compared to only $58 \%$ of deprived women (Information and Statistics Division, 2006). Despite this, the deprivation gap in breast cancer survival among women in the screening age range fell from $-3.7 \%$ for women diagnosed during $1986-1990$ to $-0.9 \%$ for women diagnosed during 1996-2000 (data not shown).

Prostate cancer incidence and survival increased rapidly since the mid-1990s, both in the United Kingdom (Majeed et al, 2000; Pashayan et al, 2006a, b) and in other countries (Etzioni et al, 2002; Ciatto et al, 2005). The trends are partly attributable to increased use of prostate-specific antigen (PSA) testing (Brewster et al, 2000), which identifies some cancers that would otherwise have remained asymptomatic and nonlethal (Pashayan et al, 2006a,b). The very rapid increase both in survival ( $11 \%$ every 5 years) and in the deprivation gap in survival (reaching $-6.9 \%$ in $1996-2000$ ) is very similar to the pattern observed in England and Wales (Coleman et al, 2004), and appears likely to reflect unequal use of the PSA test within different socioeconomic groups.

Bladder cancer survival increased between 1986-1990 and 1991-1995, but then fell substantially for patients diagnosed

\section{REFERENCES}

Banks E, Beral V, Cameron R, Hogg A, Langley N, Barnes I, Bull D, Reeves G, English R, Taylor S, Elliman J, Harris C (2002) Comparison of various characteristic of women who do and do not attend for breast cancer screening. Breast Cancer Res 4: R1

Berkson J, Gage RP (1950) Calculation of survival rates for cancer. Proc Staff Meet Mayo Clin 25: 270-286

Brewster DH, Fraser LA, Harris V, Black RJ (2000) Rising incidence of prostate cancer in Scotland: increased risk or increased detection? $\mathrm{Br} J$ Urol 85: 463-473

Brewster DH, Thomson CS, Hole DJ, Black RJ, Stroner PL, Gillis CR, on behalf of the Scottish Cancer Therapy Network (2001) Relationship between socioeconomic status and tumour stage in patients with breast, colorectal, ovarian and lung cancer: results from four national, population based studies. BMJ 322: 830-831

Campbell NC, Elliot AM, Sharp L, Ritchie LD, Cassidy J, Little J (2002) Impact of deprivation and rural residence on treatment of colorectal and lung cancer. Br J Cancer 87: 585-590

Carstairs V (1995) Deprivation indices: their interpretation and use in relation to health. J Epidemiol Community Health 49: s3 -s8

Ciatto S, Gervasi G, Bonardi R, Frullini P, Zendron P, Lombardi C, Crocetti E, Zappa M (2005) Determining overdiagnosis by screening with DRE/TRUS of PSA (Florence pilot studies, 1991-1994). Eur J Cancer 41: $411-415$

Coleman MP, Babb P, Damiecki P, Grosclaude P, Honjo S, Jones J, Knerer G, Pitard A, Quinn M, Slogget A, De Stavola BL (1999) Cancer Survival Trends in England and Wales, 1971 - 1995: Deprivation and NHS Region. (Studies in Medical and Population Subjects No. 61). London: The Stationery Office

Coleman MP, Gatta G, Verdecchia A, Estève J, Sant M, Storm H, Allemani C, Ciccolallo L, Santaquilani M, Berrino F, the EUROCARE Working Group (2003) EUROCARE-3 summary: cancer survival in Europe at the end of the 20th century. Ann Oncol 14: v128-v149

Coleman MP, Rachet B, Woods LM, Mitry E, Riga M, Cooper N, Quinn MJ, Brenner H, Estève J (2004) Trends and socioeconomic inequalities in cancer survival in England and Wales up to 2001. Br J Cancer 90: $1367-1373$

Estève J, Benhamou E, Croasdale M, Raymond L (1990) Relative survival and the estimation of net survival: elements for further discussion. Stat Med 9: 529-538 during 1996-2000. This appears to be due mainly to a change in the coding of invasive bladder malignancy: in 1995, European recommendations changed to reclassify some papillary urothelial tumours as borderline malignancy (ICD-10 D41.4) or in situ (ICD10 D09.0), rather than invasive. As a result, incidence rates for invasive malignancy of the bladder in Scotland fell by $50 \%$ in men and $40 \%$ in women between 1996 and 2003 (Information and Statistics Division, 2007). After removal of tumours that had been reclassified as noninvasive, which have a much better prognosis, recorded survival for invasive bladder cancers was lower. The deprivation gap in survival also increased in the late 1990s, reaching $-7 \%$ by $1996-2000$.

\section{CONCLUSION}

Cancer survival in Scotland has improved for all socioeconomic groups, but the increase has been greater for more affluent groups, and socioeconomic inequalities in survival have increased. Possible explanations include widening socioeconomic differences in stage at diagnosis and in access to optimal diagnosis and treatment. The widening socioeconomic gap in cancer survival cannot be attributed to increasing differences in background mortality, since the use of relative survival with deprivationspecific life tables removes these differences in the analysis. In the context of increasing survival, however, socioeconomic differences in comorbidity may also be relevant, particularly if they influence the clinical decision to provide more effective but more aggressive treatment.
Etzioni R, Penson D, Legler JM, di Tommaso D, Boer R, Gann PH, Feuer EJ (2002) Overdiagnosis due to prostate-specific antigen screening: lessons from US prostate cancer incidence trends. J Natl Cancer Inst 94: 981 - 990

Faivre-Finn C, Bouvier-Benhamiche AM, Phelip JM, Manfredi S, Dancourt V, Faivre J (2002) Colon cancer in France: evidence for improvement in management and survival. Gut 51: 60-64

General Register Office for Scotland (2006) General register office for Scotland web site. GRO, www.gro-scotland.gov.uk,accessed 1 September 2006

Griffiths C, Fitzpatrick J (2001) Geographic Variations in Health (Decennial Supplements No. 16) London: The Stationery office

Grizzle JE, Starmer CF, Koch GG (1969) Analysis of categorical data by linear models. Biometrics 25: 489-504

Guyot F, Faivre J, Manifefi S, Meny B, Bonithon-Kopp C, Bouvier AM (2005) Time trends in the treatment and survival from recurrence of colorectal cancer. Ann Oncol 16: 756-761

Hole DJ, McArdle CS (2002) Impact of socioeconomic deprivation on outcome after surgery for colorectal cancer. Br J Surg 89: 586-590

Information and Statistics Division (2006) National screening programmes. Information and Statistics Division, NHS Scotland, www.isdscotland.org/ cancer,accessed 7 October 2006

Information and Statistics Division (2007) Cancer information programme. Information and Statistics Division, www.isdscotland.org/cancer, accessed 2 April 2007

Ionescu MV, Carey F, Tait IS, Steele RJC (1998) Socioeconomic status and stage at presentation of colorectal cancer. Lancet 352: 1439

Jack RH, Guillford MC, Ferguson J, Møller H (2006) Explaining inequalities in access to treatment in lung cancer. J Eval Clin Pract 12: 573-582

Katz SJ, Hofer TP (1994) Socioeconomic disparities in preventive care persist despite universal coverage. Breast and cervical cancer screening in Ontario and the United States. JAMA 272: 530-534

Kogevinas M, Porta M (1997) Socio-economic differences in cancer survival: a review of the evidence. In Social Inequalities and Cancer. IARC Scientific Publication No. 138 Kogevinas M, Pearce N, Susser M, Boffetta P (eds) pp 177-206. Lyon: IARC

Kothari AR, Birch S (2004) Individual and regional determinants of mammography uptake. Can J Public Health 95: 290-294

Louwman JW, van de Poll-Franse LV, Fracheboud J, Roukema JA, Coebergh JW (2007) Impact of a programme of mass mammography 
screening for breast cancer of socio-economic variation in survival: a population-based study. Breast Cancer Res Treat [E-pub ahead of print]

MacKie RM, Bray CA, Hole DJ, Morris A, Nicolson M, Evans A, Doherty V, Vestey J, on behalf of Scottish Melanoma Group (2002) Incidence of and survival from malignant melanoma in Scotland: an epidemiological study. Lancet 360: 587-591

MacKie RM, Hole DJ, Hunter JAA, Rankin R, Evans A, MacLauren K, Fallowfield M, Hutcheon A, Morris A, on behalf of the Scottish Melanoma Group (1997) Cutaneous malignant melanoma in Scotland: incidence, survival and mortality, 1979-1994. BMJ 315: 1117-1121

Mackillop WJ, Zhang-Salomons J, Groome PA, Pazat L, Holowaty E (1997) Socioeconomic status and cancer survival in Ontario. J Clin Oncol 15: $1680-1689$

Madison T, Schottenfeld D, James SA, Schwartz AG, Gruber SB (2004) Endometrial cancer: socioeconomic status and racial/ethnic differences in stage at diagnosis, treatment and survival. Am J Public Health 94: $2104-2111$

Maheswaran R, Pearson T, Jordan H, Black D (2006) Socioeconomic deprivation, travel distance, location of service, and uptake of breast cancer screening in North Derbyshire, UK. J Epidemiol Community Health 60: 208-212

Majeed A, Babb P, Jones J, Quinn M (2000) Trends in prostate cancer incidence, mortality and survival in England and Wales 1971-1998. BJU Int 85: $1058-1062$

Measuring Deprivation Subgroup (2004) Deprivation and Urban Rural Measurements in ISD. Edinburgh: Information and Statistics Division

Pashayan N, Powles J, Brown C, Duffy SW (2006a) Excess of prostate cancer and estimated over diagnosis associated with PSA testing in East Anglia. Br J Cancer 95: 401 - 405

Pashayan N, Powles J, Brown C, Duffy SW (2006b) Incidence trends of prostate cancer in East Anglia, before and during the era of PSA diagnostic testing. $\mathrm{Br} J$ Cancer 95: 398-400

Quinn M, Wood H, Cooper N, Rowan S (eds) (2005) Cancer Atlas of the United Kingdom and Ireland 1991-2000. Studies on Medical and Population subjects No. 68. London: The Stationery Office

Royston P, Ambler G (1998) Multivariable fractional polynomials. STB 43 $24-32$
Schrijvers CT, Coebergh JW, Mackenbach JP (1997) Socioeconomic status and comorbidity among newly diagnosed cancer patients. Cancer 80: $1482-1488$

Schrijvers CT, Coebergh JW, van der Heijden LH, Mackenbach JP (1995a) Socioeconomic variation in cancer survival in the Southeastern Netherlands 1980-1989. Cancer 75: 2946-2952

Schrijvers CT, Mackenbach JP, Lutz J-M, Quinn M, Coleman MP (1995b) Deprivation, stage at diagnosis and cancer survival. Int J Cancer 63: $324-329$

Scottish Cancer Intelligence Unit (2000) Trends in Cancer Survival in Scotland 1971-1995,. Edinburgh: Information and Statistics Division

Scottish Cancer Intelligence Unit (2004) Trends in Cancer Survival in Scotland 1977-2001, Information and Statistics Division, http:// www.isdscotland.org/isd/files/Survival_summary_7701.pdf, accessed 1 September 2006

Singh GK, Miller BA, Hankey BF, Edwards BK (2003) Area Socioeconomic Variations in the US; Cancer Incidence, Mortality, Stage, Treatment, and Survival, 1975-1999. Bethesda, MD: National Cancer Institute. NCI Cancer Surveillance Monograph Series, Number 4

Statacorp (2004) STATA statistical software. [8.0]. College Station, TX: Stata Corporation

Ward E, Jemal A, Cokkinides V, Singh GP, Cardines C, Ghafoor A, Thun M (2004) Cancer disparities by race/ethnicity and socioeconomic status. $C A$ Cancer J Clin 54: 78 - 93

Woods LM, Rachet B, Coleman MP (2005) Choice of geographic unit influences socioeconomic inequalities in breast cancer survival. Br J Cancer 92: 1279-1282

Woods LM, Rachet B, Coleman MP (2006) Origins of socio-economic inequalities in cancer survival: a review. Ann Oncol 17: 5-19

Wrigley H, Roderick P, George S, Smith J, Mullee M, Goddard J (2005) Inequalities in survival from colorectal cancer: a comparison of the impact of deprivation, treatment and host factors on observed and cause specific survival. J Epidemiol Community Health 57: 301 -309

Yu XQ, O'Connell DL, Gibberd RW, Armstrong BK (2005) A population-based study from New South Wales, Australia 1996-2001: area variation in survival from colorectal cancer. Eur J Cancer 41: $2715-2721$ 